\title{
Lions under the Throne: the Constitutional Implications of the Debate on Prisoner Enfranchisement
}

\author{
Georgina Bryan *
}

\begin{abstract}
This article considers the constitutional implications of the tenor of the enduring debate on the United Kingdom's compliance with the ruling of the European Court of Human Rights (ECtHR) in Hirst v United Kingdom (No. 2) [2005] ECtHR 74025/01. Discussion of the enfranchisement of prisoners has been characterised by parliamentary reluctance to engage with the nexus between law and politics, and a strong tendency for concerns about the ECtHR to spill over into reckless denigration of the legal sphere as a whole. As such, the tone of debate on this high-profile issue is liable to erode mutual respect between the legislature and the courts, and to diminish the perceived legitimacy of the legal system. In a nation with an uncodified constitution, the effect of such erosion should not be underestimated. The true danger of the Hirst debate, this article contends, is that continued non-compliance will entrench mistrust of law, the rule of law and the judiciary, thereby allowing concerns about the Strasbourg court not only to undermine the UK's international standing, but also to destabilise the constitutional balance closer to home.
\end{abstract}

\section{Keywords}

Prisoner enfranchisement, ECHR compliance, Parliamentary sovereignty, rule of law

In Hirst v United Kingdom (No 2) ${ }^{1}$ (Hirst), the European Court of Human Rights $(E C t H R)$ determined that UK legislation rendering the vast majority of prisoners legally incapable of voting was incompatible with the European Convention on

BA (Cantab); Bar Professional Course Training Student.

1 Hirst $v$ United Kingdom (No 2) [2005] ECtHR 74025/01.

Copyright $\odot$ the Author(s).

This work is licensed under a Creative Commons Attribution-NonCommercial-NoDerivs 3.0 License. 
Human Rights $(E C H R) .^{2}$ It might have been expected that the UK, commanding an impressive record of compliance with ECtHR judgments, would have passed legislation to bring the provision in question within the bounds of acceptability outlined in Hirst without delay. ${ }^{3}$ Yet seven years later, the offending legislation remains on the statute books. Parliament, as it made clear in a vote in February 2011, is staunchly against compliance with the Strasbourg judgment. ${ }^{4}$ The legislature is largely opposed to the enfranchisement of prisoners but-crucially-is also of the opinion that 'legislative decisions of this nature should be a matter for democratically-elected lawmakers. ${ }^{5}$ As Gary Streeter MP put it, with only a dash of polemic, ' $\mathrm{t}$ ] his matter is not really about whether prisoners in this country have the right to vote, but about whether this House has the right to make its own laws for its own people. 6

Parliamentary debate and media commentary have largely reduced the Hirst question to a battle between the political and the legal. The rule of law, we are told, demands compliance with the Strasbourg judgment, while parliamentary sovereignty dictates that to comply would be to sacrifice the autonomy of the legislature. Parliamentary sovereignty and the rule of law-and politics and law by extension-are pitted against each other as natural enemies. However, this framework of opposition is not only a misrepresentation of, but is also potentially damaging to, the delicate balance of the constitution. Parliamentary sovereignty and the rule of law should not be regarded as rivals vying for pre-eminence. Rather, they operate within a framework of fruitful tension characterised by mutual respect and underpinned by the perceived legitimacy of the executive, legislature and judiciary. It is this mutual respect and perceived legitimacy, so crucial to the stability of the constitution, which the Hirst debate threatens to seriously undermine.

This study will unpick the dichotomy which has characterised the debate thus far and advocate compliance with Hirst on two interconnected grounds.

2 Convention for the Protection of Human Rights and Fundamental Freedoms, 4 November 1950, 213 UNTS 222.

3 For UK compliance records see Equality and Human Rights Commission, 'Research report 83: The UK and the European Court of Human Rights', 143-5 <http://www.equalityhum anrights.com/uploaded_files/research/83._european_court_of_human_rights.pdf $>$ [accessed 1 March 2013].

4 House of Commons Debates, 10 February 2011, col 584 <http://www.publications.parlia ment.uk/pa/cm201011/cmhansrd/cm110210/debtext/110210-0001.htm\#11021059000001> [accessed 1 March 2013]. The motion was passed 234 to 22.

5 Ibid, col 493.

6 Ibid, col 505. 
First, when the unhelpful political/legal dichotomy is removed, popular arguments against compliance lose their standing and rights-based arguments for enfranchisement prevail. Secondly, compliance would mitigate the constitutional damage already done by the tenor of parliamentary discussion of this issue. Compliance, of course, poses its own legal questions, and this study will conclude by considering the different potential models of compliance in the light of ECtHR judgments, the substantive question and Parliament's wider concerns about the ECtHR.

\section{The current situation}

The legal provision at the heart of the furore is section 3 of the Representation of the Peoples Act 1983 (UK):

1. A convicted person during the time that he is detained in a penal institution in pursuance of his sentence or unlawfully at large when he would otherwise be so detained is legally incapable of voting at any parliamentary or local government election.

This legislation was challenged when a convicted prisoner sued the UK for denying him the vote. Having failed in the High Court, where the legislation was held to be a legitimate and proportionate interference with the right to vote, ${ }^{7}$ John Hirst proceeded to Strasbourg. At the ECtHR, he argued on the basis of a violation of his rights under Articles 10 and 14 of the ECHR and Article 3 of Protocol No $1{ }^{8}$ claiming just satisfaction under Article 41 of the ECHR. The Grand Chamber held that the right to vote is 'not a privilege' and that therefore 'the presumption in a democratic State must be one of inclusion', but that the right was not absolute and that contracting states must be allowed a margin of appreciation. ${ }^{9}$ As the UK ban was deemed 'general, automatic and indiscriminate', it was held to fall outside this margin and violate Article 3 of Protocol No $1,{ }^{10}$ which requires 'free elections at reasonable intervals by secret

\footnotetext{
${ }^{7} R v$ Secretary of State for the Home Department, Ex parte Pearson and Martinez; Hirst $v$ AttorneyGeneral [2001] EWHC Admin 239.

${ }^{8}$ Protocol to the Convention for the Protection of Human Rights and Fundamental Freedoms, 20 March 1952, 213 UNTS 262.

9 Hirst, above n 1, paras 59-60.

${ }^{10}$ Ibid, para 82 .
} 
ballot, under conditions which will ensure the free expression of the opinion of the people in the choice of the legislature'.

As the UK has a treaty obligation 'to abide by the final judgment' of the ECtHR in any decision to which it is a party, ${ }^{11}$ one might have assumed that there would be little to report from this point; the UK would simply introduce amending legislation without delay. In this exceptional case, however, Parliament has refused to comply. The legislature does not want to enfranchise prisoners and asserts that the ECtHR cannot force its hand. The Court of Appeal in $R$ (Chester) $v$ Secretary of State for Justice and Another has held that it is not the business of domestic courts to intervene in these 'delicate and difficult' choices, on the basis that the decision 'is a political responsibility and that is where it should remain.' ${ }^{12}$

On Thursday 10 February 2011, a House of Commons majority passed the following motion proposed by David Davis MP:

That this House notes the ruling of the European Court of Human Rights in Hirst $v$ the United Kingdom in which it held that there had been no substantive debate by members of the legislature on the continued justification for maintaining a general restriction on the right of prisoners to vote; acknowledges the treaty obligations of the $\mathrm{UK}$; is of the opinion that legislative decisions of this nature should be a matter for democratically-elected lawmakers; and supports the current situation in which no prisoner is able to vote except those imprisoned for contempt, default or on remand. ${ }^{13}$

In November 2012, following much debate on and criticism of the above position, Chris Grayling presented the Voting Eligibility (Prisoners) Draft Bill. This draft bill contains three options: first, a ban for prisoners sentenced to four years or more; secondly, a ban for prisoners sentenced to more than six months; and finally, a restatement of the existing ban. Though proposals have been brought forward there remains much work to be done; the tone of the presentation of the bill can at best be described as grudging, and the government itself is 'unable to say' that the third of the proposed options is ECHR-compliant. ${ }^{14}$ Unless and

${ }^{11}$ ECHR, Art 46.

${ }^{12} R$ (Chester) $v$ Secretary of State for Justice and another [2011] 1 WLR 1436, para 35 (Laws LJ).

${ }^{13}$ House of Commons Debates, above n 4, col 493.

${ }^{14}$ Explanatory Notes to the Voting Eligibility (Prisoners) Draft Bill, para $88<\mathrm{http}: / /$ www.justi ce.gov.uk/downloads/legislation/bills-acts/voting-eligibility-prisoners/voting-eligibility-priso ners-command-paper.pdf > [accessed 5 May 2013]. 
until appropriate proposals are enacted, the UK remains in direct defiance of an ECtHR ruling and in breach of Article 46 of the ECHR.

\section{Parliamentary sovereignty and the rule of law: a dichotomy reconsidered}

Introducing his motion to the House of Commons, David Davis MP claimed it would give Parliament 'the right to assert its own right to make a decision on something of very great democratic importance. ${ }^{15}$ As the debate progressed claims of such importance were repeated many times over, but, as Dr Ed Bates has observed, 'there was very little by way of a mature debate on the merits and demits of prisoner voting. ${ }^{16}$ Nor was there considered debate on the constitutional issue; concepts such as the rule of law and parliamentary sovereignty were regularly invoked with little or no pause to consider their actual meaning or significance. The loudest voices were in staunch defence of parliamentary sovereignty and vehemently opposed to the interference of a 'kangaroo court. ${ }^{17}$ A dissenting few argued that 'we who believe in the rule of law ... cannot allow a precedent to be created whereby it is okay to pick and choose which laws we obey.18 This juxtaposition has characterised not only debate in the Commons, but the entire discussion of Hirst. The media has largely followed the lead of politicians, either championing the rule of law or declaring that 'Euro judges trample UK sovereignty.' 19

It is ironic that this crude juxtaposition has been so energetically perpetuated when the Hirst debate acutely demonstrates the connection between law and politics. A case such as this, where failure to comply with a legal judgment 'sounds at the political level', ${ }^{20}$ is a potent reminder that legal decisions are often only complied with because of political impetus and that law itself is only respected because it commands political legitimacy. Indeed, interrelation between the

\footnotetext{
${ }^{15}$ House of Commons Debates, above n 4, col 493.

${ }^{16}$ E Bates, 'Is the Attorney General right on prisoner votes and subsidiarity?', UK Human Rights Blog, 27 October 2011, <http://ukhumanrightsblog.com/2011/10/27/is-the-attorney-generalright-on-prisoner-votes-and-subsidiarity-dr-ed-bates/> [accessed 1 March 2013].

${ }^{17}$ House of Commons Debates, above n 4, col 537 (Phillip Hollobone MP).

${ }^{18}$ Ibid, col 562 (Nick Boles MP).

${ }^{19}$ J Slack, 'Euro judges trample UK sovereignty and insist: You WILL give prisoners the vote', Daily Mail, 13 April 2011, <http://www.dailymail.co.uk/news/article-1376350/Prisoner-voteban-Euro-judges-trample-UK-sovereignty-dismiss-appeal.html> [accessed 1 March 2013].

${ }^{20} R$ (Chester) $v$ Secretary of State for Justice and another [2011] 1 WLR 1436, para 27.
} 
legal and the political lies at the heart of the constitution. As Tom Hickman has noted, the 'subtle and important core' of Dicey's constitutionalism, and the feature which endures to the present day, is 'the way that the branches interact, ${ }^{21}$ accommodating both society's long-term values and its shorter-term needs. This interaction is facilitated by fruitful tension characterised by mutual respect and not hostile opposition.

When we remove the 'mystical law-politics distinction which elevates law to a suprapolitical plane, ${ }^{22}$ the Hirst question can be illuminated by a fuller understanding of the true political context. It is clear from the briefest of scans of Hansard that the main source of discontent with Hirst is serious concern about the ECtHR, which many consider to be ill-equipped to carry out its role, overwhelmed by its task and-most crucially-overstepping its jurisdiction. One of the main qualms with Hirst is the ECtHR's use of the margin of appreciation doctrine, which guarantees states some room for manoeuvre on politically sensitive issues. A vocal critic of the ECtHR's use of the doctrine is Lord Hoffmann, who has argued extra-judicially that:

[T] he Court has not taken the doctrine of the margin of appreciation nearly far enough. It has been unable to resist the temptation to aggrandise its jurisdiction and to impose uniform rules on Member States. $^{23}$

Though it is largely uncontroversial that it would be inappropriate for the ECtHR to impose one international standard in these politically and culturally sensitive matters, the question of how widely the margin should be drawn is highly contentious and understandably so. Such concerns are vitally important, and to ignore them is to short-circuit the Hirst question.

The real issue at hand, then, is how to give voice to Parliament's concerns about the ECtHR. This question is illuminated by a closer look at the views of Lord Hoffmann. Though his words have been quoted by many arguing for non-compliance, he instead speaks of hope for renegotiation:

${ }^{21}$ T Hickman, Public Law after the Human Rights Act (2010) 81.

22 D Nicol, 'Law and politics after the Human Rights Act' (2006) Public Law 722, 745.

${ }^{23}$ Lord Hoffmann, 'The Universality of Human Rights', Judicial Studies Board Annual Lecture, 19 March 2009, para 27, <http://www.judiciary.gov.uk/Resources/JCO/Docu ments/Speeches/Hoffmann_2009_JSB_Annual_Lecture_Universality_of_Human_Rights.pdf> [accessed 1 March 2013]. 
At some time the Member States of the Council of Europe will have to sit down and decide upon its future. When they do, I hope they will give more serious thought than they did in 1950 to what exactly it is supposed to do. ${ }^{24}$

Reform and renegotiation may well be possible if approached through thoughtful, formal, political discussion. The Council of Europe acknowledged this in the Brighton Declaration, which makes specific provision for long-term reform, articulating that 'a process is needed to anticipate the challenges ahead and develop a vision for the future of the Convention' and anticipating that '[a]s part of this process, it may be necessary to evaluate the fundamental role and nature of the Court. ${ }^{25}$ At present, the UK commands reasonable influence in Europe. To continue to pursue a policy of non-compliance would undermine this influence and thereby reduce Parliament's ability to act upon its wider concerns about the ECtHR.

Compliance with Hirst, therefore, is legally sound, politically expedient and the best way in which to give voice to Parliament's wider concerns about the ECtHR. It would be no infringement of sovereignty for Parliament to make a strong statement detailing parliamentary dissatisfaction with the ruling and explaining that legislation complying with Hirst will nonetheless be enacted on the basis that Parliament recognises the need to abide by the law and that the influence bestowed by an excellent record of compliance will best equip the UK to affect future reform. As Gary Streeter MP has noted, 'this matter is not really about whether prisoners in this country have the right to vote. ${ }^{26}$ Had his motion been presented to Parliament as two separate questions-the substantive and the constitutional-it would be far clearer that the real issue here is the jurisdiction of the ECtHR. As it stands, it falls to Parliament to overcome the stubborn stalemate of its own creation in order to maximise its potential to bring about real change on the constitutional issue which Hirst has come to represent.

\footnotetext{
${ }^{24}$ Ibid, para 45 .

${ }^{25}$ Council of Europe, High Level Conference on the Future of the European Court of Human Rights Brighton Declaration, 20 April 2012, Arts 30-1, $<$ http://hub.coe.int/en/20120419-brighton-declaration/> [accessed 1 March 2013].

${ }^{26}$ House of Commons Debates, above n 4, col 505.
} 


\section{Mutual respect, perceived legitimacy and the need for compliance}

The Hirst debate has not only misrepresented the delicate balance of the constitution, but has also gone some way towards actively damaging it. To represent parliamentary sovereignty and the rule of law as at continual loggerheads clearly perverts public understanding of the unwritten constitution. However, this debate has also seen parliamentarians displaying an alarming lack of respect for the rule of law and the legal profession as a whole; a tendency that threatens to pervert the balance of the constitution itself.

Anti-legal polemic has been rife throughout discussion of Hirst. Such was their zeal to assert the sovereignty of Parliament against the pernicious legal system that many parliamentarians openly declared their mistrust of the profession during the Commons debate. Steve McCabe MP prefaced his speech with 'I am not a lawyer. I am just a humble Back Bencher doing his best to represent his constituents. ${ }^{27}$ Claire Perry MP began 'I am of course not a lawyer, so I speak, I hope, the language of common sense. ${ }^{28}$ Ian Davidson MP, in fear that '[w]e are in danger of turning this debate, which is about basic, simple questions, into a lawyers' talkfest', felt the need to declare that:

Not only am I not a lawyer, I have never been a lawyer, and I have no intention of ever becoming a lawyer. As far as I am aware, no one in my family unto the nth generation has ever been a lawyer. ${ }^{29}$

Throughout the debate a lack of legal training was worn as a badge of honour, the implication being that the whole issue of prisoners' voting rights is a storm in a teacup brewed by 'lawyers ... circling like vultures, waiting for convicted men and women to make financial gain from this farce. ${ }^{30}$

Two recent extra-judicial observations of Lord Neuberger illuminate the problems such pronouncements may cause. In the Second Lord Alexander of Weedon Lecture, the Master of the Rolls observed that 'perceived legitimacy is of the essence where there is no written constitution.' ${ }^{31}$ In another recent lecture, he stressed the importance of mutual respect:

\footnotetext{
${ }^{27}$ Ibid, col 541.

${ }^{28}$ Ibid, col 552.

${ }^{29}$ Ibid, col 563.

${ }^{30}$ Ibid, col 581 (Richard Drax MP).

${ }^{31}$ Lord Neuberger of Abbotsbury, Master of the Rolls, 'Who are the Masters now?', Second Lord Alexander of Weedon Lecture, 6 April 2011, para 16, <http://www.judiciary.gov.uk/Res
} 
Mutual respect between the judges and the politicians is essential ... [I]f they slang each other off in public, members of the judiciary and members of the other two branches of government will undermine each other, and, inevitably, the constitution of which they are all a fundamental part, and on which democracy, the rule of law, and our whole society rests. ${ }^{32}$

Having allowed its criticisms of the ECtHR to spill over into what, at times, can only be termed vilification of the entire legal profession, Parliament has undoubtedly gone some way down this path towards constitutional destabilisation. The lack of respect demonstrated for the legal profession as a whole surely at least equals the 'barrage of hostile criticism'33 levelled at the ECtHR, for which the debate has been heavily criticised, and undermines the perceived legitimacy of the legal sphere.

Further opposition to the judgment, or the enactment of the third option in the draft bill, is unlikely to light the touchpaper of a constitutional crisis. It would, however, consolidate the irresponsibly negative representation of the legal sphere already perpetuated, undermining the mutual and perceived legitimacy which is so crucial to the constitution in the longer term. Compliance with Hirst would counter this dangerous tendency towards destabilisation by sending a message that even when it disagrees with the law, even when it may technically be able to shirk away from the law, Parliament will obey the law and respect the constitutional importance which it commands.

\section{Towards a model of compliance}

There must, then, be some form of compliance. What exactly this means, however, is complicated by the line of cases following Hirst. For a measure to be proportionate, and therefore acceptable, Hirst held there must be 'a discernible and sufficient link between the sanction and the conduct and circumstances of the

ources/JCO/Documents/Speeches/mr-speech-weedon-lecture-110406.pdf> [accessed 1 March 2013].

${ }^{32}$ Lord Neuberger of Abbotsbury, Master of the Rolls, 'Where Angels Fear to Tread', Holdsworth Club 2012 Presidential Address, 2 March 2012, para 37, <http://www.judiciary.gov.uk/Re sources/JCO/Documents/Speeches/mr-speech-holdsworth-lecture-2012.pdf> [accessed 1 March 2013].

${ }^{33}$ M O'Boyle, 'The Future of the European Court of Human Rights' (2011) 12 German Law Journal $1862,1862$. 
individual concerned' ${ }^{34}$ Frodl v Austria (Frodl), following Hirst, stated that '[u]nder the Hirst test ... it is an essential element that the decision on disenfranchisement should be taken by a judge, taking into account the particular circumstances, and that there must be a link between the offence committed and issues relating to elections and democratic institutions. ${ }^{35}$ In the later case of Greens and MT $v$ United Kingdom, considering the UK's ongoing non-compliance, the ECtHR distanced itself from the interpretation of Hirst given in Frodl, clarifying that 'the Grand Chamber in Hirst declined to provide any detailed guidance as to the steps which the United Kingdom should take' and that 'a wide range of policy alternatives are available to the Government. ${ }^{36}$ As Sophie Briant has cogently argued, this distancing was strictly correct; Hirst in fact held that judicial decision-making was desirable, not obligatory, and did not specify where the 'discernible and sufficient link' would be present. ${ }^{37}$

How, then, should the government proceed? It is submitted that Parliament should legislate to implement the Hirst test as interpreted in Frodl. By this model, prisoners would be disenfranchised by judicial decision when their offences are linked to 'issues relating to elections and democratic institutions. ${ }^{38}$ Dr Eric Metcalfe's suggestion that Guy Fawkes would have been a good candidate for disenfranchisement, his offence 'striking against the democratic order,', indicates how rare such cases would be. This form of compliance commands two distinct advantages: it is underpinned by a coherent ideological approach to the substantive issue at hand, and it minimises the chance of further legal challenge. As such, it is the model which would allow Parliament to counter the constitutional damage which has already been done and finally move on from Hirst.

The alternative course of action would be to enact legislation on the basis of a looser reading of the Hirst test, by which not only electoral crimes hold a 'discernible and sufficient link' to disenfranchisement. ${ }^{40}$ Rather, particularly severe crimes would be deemed discernibly and sufficiently linked to the sanction.

\footnotetext{
${ }^{34}$ Hirst, above n 1, para 71.

${ }^{35}$ Frodl v Austria [2010] ECtHR 20201/04, para 34.

${ }^{36}$ Greens and MT v United Kingdom [2010] ECtHR 60041/08 and 60054/08, paras 113-14.

${ }^{37} \mathrm{~S}$ Briant, 'The requirements of prisoner voting rights: mixed messages from Strasbourg', (2011) 70 CLJ 279, 281. See Hirst, above n 1, paras 71-2.

${ }^{38}$ Frodl, above n 35, para 34.

${ }^{39}$ Political and Constitutional Reform Committee, "Voting by convicted prisoners: summary of evidence: Fifth Report of Session 2010-11', 9 February 2011, at Ev 14 (Q38), <http://www.publica tions.parliament.uk/pa/cm201011/cmselect/cmpolcon/776/776.pdf> [accessed 1 March 2013].

${ }^{40}$ Hirst, above n 1, para 71.
} 
This alternative, adopted by the government in the first and second options proposed in the draft bill, has the advantage of popularity; it would appease those politicians and publications that worry that the Hirst affair will see 'rapists, paedophiles and murderers' enfranchised. ${ }^{41}$ However, it poses two serious difficulties.

First, the substantive basis underpinning the motivation for this looser reading is decidedly shaky. It is often claimed that the convict 'has broken their contract with society to such a serious extent that they have lost all these rights: their liberty, their freedom of association and their right to vote. ${ }^{42}$ The notion of the social contract, indeed, is used in the introduction to the draft bill itself (paragraph 9). Behind this notion is the idea that 'when people are convicted and sentenced to imprisonment, they lose the moral authority to vote. ${ }^{43}$ These arguments from social contract and moral authority are entirely unconvincing. This distorted social contract theory ignores the fact that society has obligations towards the individual that are not conditional: a highly dangerous message and one which is patently incorrect. The argument from moral authority is similarly unsound: in a democracy with universal suffrage the votes of all-even those who might be considered morally lacking - count equally.

Secondly, a model of compliance based on a loose reading of the Hirst test also falls down on pragmatic grounds. Sophie Briant is surely correct to argue that 'challenges are particularly likely if ... legislative proposals fall short of Frodl's interpretation of Hirst. ${ }^{44}$ Were the UK to concede to comply with Hirst in order to restore faith in the legal system and maintain the UK's bargaining position, it would be entirely counterproductive to implement legislation which would take the nation back to the ECtHR in a few months' time. Further, it is quite possible that if new legislation were to be challenged in Strasbourg, the ECtHR would take a view akin to that held in Frodl. Though Frodl was perhaps overzealous in its reading of Hirst, it surely presents the natural conclusion to the reasoning of the case; where voting is considered a right, and the presumption is accordingly against disenfranchisement, the test for a 'discernible and sufficient link' will be a stringent one.

\footnotetext{
${ }^{41}$ House of Commons Debates, above n 4, col 529 (Michael McCann MP).

${ }^{42}$ Ibid, col 494 (David Davis MP).

${ }^{43}$ Ibid, col 547 (Rehman Chishti MP).

${ }^{44}$ Briant, above n 38, 282.
} 


\section{Concluding thoughts}

The Hirst debate, then, is one of serious constitutional import. If non-compliance continues, Parliament will firmly establish the negative view of the rule of law and the legal sphere which has already been purveyed, undermining the mutual respect and perceived legitimacy central to the unwritten constitution. If the government seeks to appease the ECtHR by introducing legislation in line with the draft bill on the basis of a loose reading of the Hirst test, ideas of 'moral authority' and 'social contract' will have been introduced into the law, quite contrary to human rights and the principle of universal suffrage. However, if the government were to take the perhaps unlikely step of calling Parliament to legislate in line with Frodl, the Hirst debate could be turned around to restore mutual respect between legal and political powers and restore perceived legitimacy for the rule of law. The question of prisoners' voting rights may not be a constitutional crisis but it will surely be a constitutional turning point, for better or for worse.

The distinguished lawyer and politician Francis Bacon once counselled:
[A]nd let no man weakly conceive that just laws and true policy have any antipathy; for they are like the spirits and sinews, that one moves with the other. Let judges also remember, that Solomon's throne was supported by lions on both sides: let them be lions, but yet lions under the throne ..... ${ }^{45}$

The Hirst debate has been characterised by parliamentarians' refusal to accept this interconnection between 'just laws and true policy' which is the lifeblood of the body politic. Understandable concerns about the ECtHR have been allowed to engulf the issue and spill into reckless denigration of the legal sphere as a whole. This has doubtlessly already affected public perceptions, undermining the rule of law and thus recklessly swaying the delicate balance of the unwritten constitution. The draft bill, limited and grudging as it is, will do nothing to remedy the situation. Debate on the proposals put forward is likely simply to involve more of the fruitless and damaging point-scoring which has characterised discussion of the Hirst question so far, and the strength of any legislation born of such debate is likely to be questionable at best. The true danger of the Hirst debate, however, is that continued non-compliance will entrench mistrust of law, the rule of law and the judiciary, thereby allowing concerns about the ECtHR

${ }^{45}$ F Bacon, 'Of Judicature' (1612), reprinted in Essays or Counsels, Civil and Moral (1992) 170, 174. 
to destabilise the constitutional balance in this country. The government must now put an end to this stubborn stalemate. If it does otherwise, the judiciary will remain under the throne but, as their perceived legitimacy erodes further, may not be lions for long. 